\title{
Arquivamento do Inquérito Policial: uma análise sobre a imutabilidade dos seus efeitos
}

\author{
Decision to close the Policial Investigation: \\ an analysis of the immutability of its effects
}

Antonio Eduardo Ramires Santoro ${ }^{1}$

Universidade Federal do Rio de Janeiro - Rio de Janeiro/RJ

Universidade Católica de Petrópolis - Petrópolis/RJ

antoniosantoro@antoniosantoro.com.br

lattes.cnpq.br/9190879263950156

orcid.org/0000-0003-4485-844X

Resumo: A imutabilidade do ato de arquivamento do inquérito policial e das peças de informação é um tema pouco regulado em lei e parcamente problematizado na teoria processual penal brasileira, especialmente diante da edição da Súmula n 524 do STF no ano de 1969. O problema que se enfrentou neste trabalho é se o arquivamento do inquérito policial é ato judicial cujo conteúdo se torna imutável pela coisa julgada. Metodologicamente realizou-se uma revisão bibliográfica para revisitar os temas da natureza jurídica do ato de arquivamento e da autoridade da coisa julgada, bem como realizou-se uma análise da

1 Professor Titular de Direito Processual Penal do IBMEC/RJ. Professor Adjunto de Direito Processual Penal e Prática Penal do Programa de Pós-Graduação em Direito da Faculdade Nacional de Direito da Universidade Federal do Rio de Janeiro - FND/UFRJ. Professor Adjunto do Programa de Pós-Graduação em Direito da Universidade Católica de Petrópolis - UCP. Coordenador do Grupo de Pesquisa "O Sistema Penal sob Olhar Crítico" da UFRJ/UCP. Pós-Doutor em Direito Penal e Garantias Constitucionais pela Universidad Nacional de La Matanza - Argentina. Doutor e Mestre em Filosofia pela UFRJ. Mestre em Direito Penal Internacional pela Universidad de Granada - Espanha. Especialista em Direito Penal Econômico pela Universidade de Coimbra - Portugal. Especialista em Direito da Economia pela Fundação Getúlio Vargas. Graduado em Direito pela UERJ. Licenciando em História pela UNIRIO. Advogado criminalista. 
aplicabilidade do verbete sumular. Concluiu-se que o ato de arquivamento tem natureza de sentença que faz coisa julgada formal e, quando enfrenta o mérito, faz coisa julgada material, tornando seus efeitos imutáveis.

Palavras-chave: arquivamento; inquérito policial; efeitos; coisa julgada; imutabilidade.

ABSTRACT: The immutability of the decision to close the police investigation and the other information is a subject that is not very much regulated by law and is problematic in Brazilian criminal procedural theory, especially in view of the edition of the Precedent 524 of the brazilian Supreme Court in 1969. The problem that faced in this work is whether the decision to close the police investigation is a judicial act whose content becomes immutable by the res judicata. Methodologically a bibliographic review was carried out to revisit the subjects of the legal nature of the decision to close the investigation and the authority of the res judicata, as well as an analysis was made of the applicability of the precedente 524. It was concluded that the decision to close the police investigation is a final judgment and, when the decision to close the investigation judge the merits, the res judicata became immutable.

KeYwords: archiving act; police investigation; effects; res judicata; immutability.

SUMÁRıo: Introdução; 1 Natureza jurídica do ato de arquivamento do inquérito policial; 2 Hipóteses de arquivamento do inquérito policial; 3 Desarquivamento e mutabilidade do arquivamento; 4 Coisa Julgada formal e material do ato de arquivamento do inquérito policial: imutabilidade dos efeitos do arquivamento; Considerações Finais; 5 Referências.

\section{INTRODUÇÃO}

O arquivamento do inquérito policial, a par de se tratar de tema de extrema relevância no processo penal, é parcamente problematizado em discussões acadêmicas. Mesmo o Código de Processo Penal trata do 
arquivamento do inquérito policial em apenas 5 (cinco) artigos (artigo $17^{2}$, artigo $18^{3}$, artigo $28^{4}$, artigo 67 , inciso $\mathrm{I}^{5}$ e artigo $779^{6}$ ).

Mais especificamente, a discussão sobre a imutabilidade dos efeitos do arquivamento parece ter sido ignorada diante do disposto no artigo 18 e do que foi definido na Súmula n ${ }^{0} 524$ do Supremo Tribunal Federal ${ }^{7}$, reduzindo todas as discussões à interpretação desses enunciados a respeito do desarquivamento.

Todavia, pouco se fala sobre a aplicabilidade ou não desse enunciado sumular, que foi publicado no Diário de Justiça do dia 12 de dezembro de 1969, após a reforma do Código de Processo Penal de 2008, mais especificamente as alterações realizadas pela Lei $\mathrm{n}^{0} 11.719$, que revogou o artigo $43^{8}$, até então o dispositivo base para análise das hipóteses de arquivamento.

O problema que se pretende tratar é: o arquivamento do inquérito policial é ato judicial cujo conteúdo se torna imutável pela coisa julgada?

2 “Art. 17. A autoridade policial não poderá mandar arquivar autos de inquérito."

3 “Art. 18. Depois de ordenado o arquivamento do inquérito pela autoridade judiciária, por falta de base para a denúncia, a autoridade policial poderá proceder a novas pesquisas, se de outras provas tiver notícia."

4 “Art. 28. Se o órgão do Ministério Público, ao invés de apresentar a denúncia, requerer o arquivamento do inquérito policial ou de quaisquer peças de informação, o juiz, no caso de considerar improcedentes as razões invocadas, fará remessa do inquérito ou peças de informação ao procurador-geral, e este oferecerá a denúncia, designará outro órgão do Ministério Público para oferecê-la, ou insistirá no pedido de arquivamento, ao qual só então estará o juiz obrigado a atender.”

5 “Art. 67. Não impedirão igualmente a propositura da ação civil: I - o despacho de arquivamento do inquérito ou das peças de informação;"

6 "Art. 779. O confisco dos instrumentos e produtos do crime, no caso previsto no art. 100 do Código Penal, será decretado no despacho de arquivamento do inquérito, na sentença de impronúncia ou na sentença absolutória."

7 Súmula 524 do STF: "Arquivado o inquérito policial, por despacho do juiz, a requerimento do promotor de justiça, não pode a ação penal ser iniciada, sem novas provas."

8 “Art. 43. A denúncia ou queixa será rejeitada quando: I - o fato narrado evidentemente não constituir crime; II - já estiver extinta a punibilidade, pela prescrição ou outra causa; III - for manifesta a ilegitimidade da parte ou faltar condição exigida pela lei para o exercício da ação penal." 
Trabalhar-se-á com a hipótese de que o arquivamento do inquérito policial é ato judicial cujo conteúdo decisório se torna imutável caso haja enfrentamento do mérito da causa.

Metodologicamente o problema será enfrentado por meio de uma revisão bibliográfica destinada a explorar os conceitos que no âmbito da dogmática processual penal são fundamentais para o seu enfrentamento, a saber: a natureza jurídica do ato de arquivamento e a autoridade da coisa julgada. Também será realizada uma abordagem da interpretação dada pela doutrina e pelos tribunais superiores ao enunciado sumular $\mathrm{n}^{\circ} 524$ do Supremo Tribunal Federal.

\section{Natureza JURÍdicA do ATO DE ARQUIVAMENTO DO INQUÉRITO POLICIAL}

O Código de Processo Penal denomina, no artigo 67, "despacho" $\mathrm{o}$ ato de arquivamento. Importa dizer que o referido dispositivo prevê a possibilidade de propositura de ação civil quando pelo mesmo fato for determinado o arquivamento do inquérito policial ou das peças de informação.

Não parece, todavia, que esta nomenclatura utilizada o tenha sido de forma cientificamente rigorosa. Como, por sinal, ocorre (e ocorria muito mais antes da reforma de 2008) por todo o Código de Processo Penal, o legislador de 1941 utilizou expressões que destoam da melhor técnica processual. Veja-se, por exemplo, que a pronúncia, que tem natureza de decisão interlocutória mista, era tratada como sentença ${ }^{9} \mathrm{e}$ ainda é em alguns dispositivos não alterados pela reforma ${ }^{10}$. Ou mesmo

9 Vide $\S 1^{\circ}$ do art. 408 do CPP com a antiga redação: $\S 1^{\circ} \mathrm{Na}$ sentença de pronúncia o juiz declarará o dispositivo legal em cuja sanção julgar incurso o réu, mandará lançar-lhe o nome no rol dos culpados, recomendá-lo-á, na prisão em que se achar, ou expedirá as ordens necessárias para a sua captura.

10 Vide art. 373, inciso II: Art. 373. A aplicação provisória de interdições de direitos poderá ser determinada pelo juiz, de ofício, ou a requerimento do Ministério Público, do querelante, do assistente, do ofendido, ou de seu representante legal, ainda que este não se tenha constituído como assistente: I - omissis II - na sentença de pronúncia; 
a clara confusão que fez (e ainda permanece no texto legal) entre processo e procedimento ${ }^{11}$.

De outro lado, os artigos 17 e 18 do Código de Processo Penal denotam tratar-se de uma ordem judicial. Veja-se que o artigo 17 proíbe que a autoridade policial mande (a palavra utilizada é exatamente "mandar") arquivar o inquérito policial. Já o artigo 18 afirma que depois de "ordenado o arquivamento do inquérito pela autoridade judiciária”, somente diante de novas provas a autoridade policial poderá realizar novas pesquisas.

Desta forma resta claro que a palavra "despacho" foi usada no artigo 67 sem o menor rigor, já que está claro ser o arquivamento uma ordem emanada da autoridade judicial.

A ordem, neste caso, não é um impulso processual, o que caracterizaria o despacho (até porque o que existe é exatamente o contrário de um impulso, vez que o juiz manda parar o curso procedimental). Portanto, só pode decorrer de uma decisão judicial que soluciona uma questão posta ao julgador. Neste sentido é também a compreensão de Pacelli $^{12}$ (para quem ao ato de arquivamento são atribuídos os mesmos efeitos da impronúncia), Coutinho ${ }^{13}$ (para quem se trata de uma sentença de mérito em processo cautelar), Pitombo ${ }^{14}$ e Jardim $^{15}$.

Jardim, todavia, entende que a decisão judicial de arquivamento não é sentença por não haver processo ou jurisdição, de tal forma que na sua compreensão trata-se de uma simples decisão administrativa, mas, por ser proferida por uma autoridade judicial, é uma decisão judicial.

11 Observe-se que o Livro II tem como título "Processos em Espécie”, o Título I “Do Processo Comum” e o Título II "Dos Processos Especiais”. No entanto, o artigo 393, pós reforma, já trabalha com a classificação "procedimentos" comum e especial.

12 PACELLI, Eugênio. Curso de Processo Penal. 16 a edição. São Paulo: Atlas, 2012, p. 66.

13 COUTINHO, Jacinto, A natureza cautelar da decisão de arquivamento do inquérito policial. Revista de Processo, São Paulo, a. 18, n. 70, abr/jun, 1993, p. 55/56.

14 PITOMBO, Sérgio Marcos de Moraes. Arquivamento do inquérito policial: sua força e efeito. Revista do Advogado. São Paulo, a III, n. 11, out./dez. 1982, p. 9-15, que ainda faz a distinção que também sera realizada neste trabalho sobre a possibilidade de a decisão de arquivamento do inquérito enfrentar ou não o mérito.

15 JARDIM, Afrânio Silva. Direito Processual Penal. $6^{\mathrm{a}}$ edição. Rio de Janeiro: Forense, 1997, p. 172. 
Por outro lado, Jardim afirma que quando o juiz, aplicando o disposto no artigo 28 do CPP, ao discordar do pedido de arquivamento formulado pelo órgão do Ministério Público atuando em primeira instância remete os autos do inquérito policial ao Procurador Geral, caso este insista no arquivamento e o juiz esteja obrigado a arquivar, este ato de arquivamento não será mais uma decisão judicial, mas uma "decisão material e subjetivamente administrativa, de natureza complexa"16.

Duas questões devem ser incidentalmente enfrentadas. Uma é se o fato do juiz ser obrigado por lei a acatar a manifestação do Ministério Público (especificamente do Procurador Geral) retira a natureza de decisão judicial do ato emanado do juiz que determina o arquivamento. A segunda questão é se o ato de arquivamento tem ou não natureza de sentença.

Interessante enfrentar a primeira das duas questões com uma análise sobre a hipótese de ação penal privada em que o querelante não pede condenação em suas alegações finais. De acordo com o artigo 60, inciso III, in fine, do CPP, é uma hipótese de perempção. Neste caso o juiz é obrigado a extinguir a punibilidade e, em que pese algumas discussões sobre a natureza deste ato jurisdicional ${ }^{17}$, certo é que se trata de uma sentença. Muito embora o juiz não tenha nenhuma margem de decisão e, portanto, a palavra final do querelante (não pedindo a condenação) seja vinculante, não há qualquer voz teórica que se oponha a classificar este ato judicial como sentença.

Assim, se a lei exige que o juiz pratique o ato, cujo conteúdo foi determinado anteriormente pela manifestação vinculante de uma das partes, não há por que entender que a manifestação vinculante do Procurador Geral afaste a natureza de sentença, já que a lei atribui ao juiz a prática do ato que define uma questão ${ }^{18}$.

16 Idem.

17 Inobstante o artigo 397, inciso IV, do CPP preveja a extinção da punibilidade como hipótese de absolvição sumária, ela não está entre as hipóteses de absolvição ao final do processo, na forma do artigo 386 do CPP. TOURINHO FILHO, Fernando da Costa. Processo Penal. vol. 4. 24a edição. São Paulo: Saraiva, 2002, p. 235, afirma tratar-se de sentença definitiva em sentido lato ou terminativa de mérito. Fato é que se trata de uma sentença.

18 Parece que esta deverá ser uma importante questão enfrentada no que respeita à colaboração premiada. Afinal, deverá o juiz cumprir o acordo celebrado entre o Ministério Público (ou a Polícia) e o colaborador? Caso deva 
Quanto à segunda questão, ou seja, se o ato tem natureza de sentença, importa iniciar a análise de forma conceitual. Tradicionalmente, sob a influência de Código de Processo Civil de $1973^{19}$, define-se sentença como o ato jurisdicional que põe fim ao processo, com ou sem julgamento de mérito, compreensão que se mantém entre os teóricos do processo penal ${ }^{20}$, mesmo após as sucessivas mudanças na lei processual civil $^{21}$ e, como se exporá, também diante de sua incompatibilidade com a realidade prática do processo penal.

Não há como negar que o encerramento da relação processual de fato não ocorre no arquivamento, uma vez que a relação sequer se estabelece sem a formulação de uma acusação.

cumprir na forma acordada, estar-se-ia diante de uma sentença? Se, ao proferir uma sentença, o juiz está obrigado a cumprir o acordo que ele mesmo não celebrou, o ato judicial deixa de ser uma sentença? Essas são questões que ainda devem ser melhor enfrentadas pelos tribunais brasileiros, mas se estivermos de acordo que o acatamento de cláusulas de acordo em colaboração premiada pelo juiz não desfigura o ato judicial como sentença, não há motivo para afastar a natureza de decisão judicial do ato que arquiva o inquérito policial em decorrência de manifestação do Procurador Geral na forma do artigo 28 do CPP.

19 Artigo 162, $\S 1^{\circ}$ : "Sentença é o ato pelo qual o juiz põe termo ao processo, decidindo ou não o mérito da causa."

20 BADARÓ, Gustavo. Processo Penal. $4^{\mathrm{a}}$ edição. São Paulo: Editora Revista dos Tribunais, 2016, p. 531; LOPES JÚNIOR, Aury. Direito Processual Penal. $15^{\mathrm{a}}$ edição. São Paulo: Saraiva, 2018, p. 889.

21 O próprio $\S 1^{\circ}$ do artigo 162 , com a redação dada pela Lei $n^{\circ} 11.232 / 2005$, passou a dar importância ao conteúdo do ato como definitório e não à sua relação com o encerramento do processo: "Sentença é o ato do juiz que implica alguma das situações previstas nos arts. 267 e 269 desta Lei.”. O CPC de 2015 manteve a ideia de relação conceitual, mas a relacionou com a fase procedimental (tendo em vista que o cumprimento da sentença civil não á mais um novo processo de execução, mas uma fase, o que não ocorre no processo penal): "Ressalvadas as disposições expressas dos procedimentos especiais, sentença é o pronunciamento por meio do qual o juiz, com fundamento nos arts. 485 e 487, põe fim à fase cognitiva do procedimento comum, bem como extingue a execução". Deve se observar que o CPC também admitiu que o conceito pode ser diverso conforme o "procedimento", não estando mais vinculado à extinção do "processo". Trataremos o assunto, todavia, com as peculiaridades que fazem do direito processo penal não apenas um ramo do direito processual, rompendo com a teoria unitária do processo e incursionando na necessidade de uma teoria própria que lhe seja efetivamente adequada. 
No entanto, é possível verificar aqui mais um problema de diferença de tratamento entre determinadas situações que apresentam uma estrutura jurídica semelhante.

É o que ocorre com a decisão que, na forma do artigo 395 do CPP rejeita a denúncia ou a queixa. Não é pacífica a natureza jurídica do ato de rejeição da denúncia ou queixa. Badaró entende que se trata de uma sentença terminativa ${ }^{22}$, ao passo que Pacelli entende ser uma decisão interlocutória mista ${ }^{23}$. Para aqueles que entendem se tratar de uma sentença, é forçoso admitir que não houve o recebimento da petição inicial, ato apontado pela doutrina tradicional como o que dá início ao processo $^{24}$, portanto haveria uma sentença sem processo. No âmbito do processo penal, importante entendimento aponta o ato de recebimento da denúncia (previsto no artigo 396 do CPP) como aquele que dá início ao processo penal ${ }^{25}$. Todavia, outras posições sobre o início do processo devem ser consideradas, como aquela derivada da interpretação do texto

22 Op. cit., p. 861.

${ }^{23}$ PACELLI. Op. cit., p. 898.

${ }^{24}$ GRINOVER, Ada Pellegrini, GOMES FILHO, Antonio Magalhães e FERNANDES, Antonio Sacance. Teoria Geral do Processo. 12a edição. São Paulo: Malheiros, 1996, p. 294, também sob a influência do Código de Processo Civil de 1973, em seu artigo 263, embora o artigo 312 do atual CPC defina que a ação considera-se proposta no ato do protocolo, e não quando despachada pelo juiz, como o dispositivo do código anterior.

HABEAS CORPUS. IMPETRAÇÃO NA PENDÊNCIA DE RECURSO ESPECIAL. AÇÃO PENAL. PEREMPÇÃO. AUSÊNCIA DO QUERELANTE NA AUDIÊNCIA A QUE ALUDE O ART. 520 DO CPP. PARALISAÇÃO DO FEITO POR FALTA DE INTIMAÇÃO DE TESTEMUNHAS. 1. Não há impedimento para a impetração de habeas corpus na pendência de recurso especial, dado que, conforme orientação pretoriana, aquele remédio, de assento constitucional, não encontra óbice na legislação ordinária, em obséquio ao direito de ir e vir. 2. Segundo orientação pretoriana, não se dá a perempção pela ausência do querelante na audiência prevista no art. 520 do Código de Processo Penal, dado que ainda não instaurada a relação processual com o recebimento da queixa (art. 60, III, do Código de Processo Penal). 3. O adiamento da audiência, em virtude de entraves do mecanismo judiciário, relacionados com a intimação de testemunhas, não induz à perempção de ação penal, porquanto esta causa extintiva da punibilidade pressupõe negligência do querelante. 4. Ordem denegada. (STJ - HC: 9843 MT 1999/0053837-4, Relator: Ministro Fernando Gonçalves, Data de Julgamento: 21/03/2000, T6 - SEXTA TURMA, Data de Publicação: DJ 17.04.2000 p. 95 REVJUR vol. 271 p. 139 RSTJ vol. 135 p. 611) 
do artigo 363 do CPP, segundo o qual a relação se perfaz com a citação do acusado, ou de que o processo penal se inicia com o oferecimento da denúncia ou da queixa ${ }^{26}$. Neste caso deste último entendimento, no momento da rejeição da denúncia, já existirá processo.

No entanto, a situação no procedimento sumariíssimo ${ }^{27}$ é ainda mais clara no sentido de que pode haver sentença sem processo. Na hipótese de transação penal, por exemplo, (artigo 76 da Lei nº 9.099/95), uma vez que o Ministério Público tenha formulado uma proposta aceita pelo autor do fato assistido por seu advogado, caberá ao juiz homologá-la. Este ato do juiz é uma sentença ${ }^{28}$, sem que tenha havido o início do processo.

Pode-se argumentar que essa sentença atende a uma pretensão do Ministério Público, afinal o autor do fato deverá cumprir uma pena à qual se obrigou e, portanto, houve processo, já que existe a chamada pretensão ${ }^{29}$.

Mas, ainda no âmbito do procedimento sumariíssimo, quando autor do fato e vítima compõem na forma do artigo 74 da Lei no 9.099/95, o juiz homologa o acordo em ato considerado uma sentença irrecorrí$\operatorname{vel}^{30}$. Neste caso não há pretensão alguma deduzida, já que o Ministério Público, legitimado para deduzir a pretensão, sequer se pronunciou nos autos do procedimento.

A questão é, então, que pode haver uma sentença, seja ela a rejeição da denúncia ou queixa, seja a homologação da transação penal ou da composição dos danos civis no procedimento sumariíssimo, sem

26 MARQUES, Frederico. Elementos de Direito Processual Penal. vol. 2. $2^{\mathrm{a}}$ edição. Rio de Janeiro: Forense, 1965, p. 194/195; BADARÓ. Op. cit., p. 594/595; TOURINHO. Op. cit., p. 9. e GRECO FILHO, Vicente. Manual de Processo Penal. $10^{\mathrm{a}}$ edição. São Paulo: Saraiva, 2013, p. 419/420, sendo que para este último a relação é gradativa, se inicia com o oferecimento da denúncia ou queixa e se completa com a citação.

27 A expressão "sumariíssimo", com dois is, é usada na Seção III da Lei no 9.099/95, em divergência do artigo 394, inciso III, do CPP. Optou-se no texto pela redação dada pela Lei no 9.099 .

28 LOPES JR. Op. cit., p. 763. Para BADARÓ. Op. cit., p. 548, a sentença homologatória da transação faz coisa julgada material.

29 Entendimento Carneluttiano seguido por Afrânio Silva Jardim (a pretensão como categoria essencial ao processo em substituição à lide). Op. cit., p. 28.

30 BADARÓ. Op. cit., p. 631. Para ele se trata de uma sentença homologatória irrecorrível. 
que exista processo. Se é possível ter sentença sem processo, o conceito tradicional de sentença entendida como o ato jurisdicional que põe fim ao processo, com ou sem apreciação do mérito, carece de compatibilidade com o fenômeno prático do processo penal.

O que há de comum entre as tradicionais sentenças proferidas após o regular desenvolvimento dos atos processuais (seja a sentença de absolvição sumária prevista no artigo 397 do CPP ou as sentenças terminativas ou definitivas após a apresentação de alegações finais) e as que abordamos acima (rejeição da denúncia ou queixa, homologação da transação penal ou da composição dos danos civis) é que enfrentam ou impedem que se enfrente o caso penal ${ }^{31}$.

Desta forma, o conceito de sentença penal se afasta do conceito de sentença civil, mas trilha pelo caminho da vinculação do instituto ao conteúdo do ato, como se fez no processo civil a partir da alteração do $\S 1^{\circ}$ do artigo 162 do CPC de 1973 pela Lei $\mathrm{n}^{\circ}$ 11.232/2005 e pode ser entendida como o ato judicial que enfrenta ou impede que se enfrente o caso penal.

Não é necessário tentar adequar o ato de arquivamento do inquérito entre as tradicionais classificações da sentença. Veja-se que a tradicional classificação das sentenças em declaratórias, constitutivas e condenatórias, perdem o sentido no processo penal. Não porque o provimento pretendido pelo Ministério Púbico seria sempre condenatório. Não é. Existem ações mandamentais de natureza penal que não têm natureza condenatória, como é o caso da Revisão Criminal, cujo provimento pleiteado é (des) constitutivo. Ou mesmo o Habeas Corpus, sendo possível pensar em uma hipótese de Habeas Corpus preventivo meramente declaratório em que o impetrante pleiteia a declaração de extinção da punibilidade de fato pela prescrição antes que haja propositura de ação penal. Não se olvide da própria sentença que homologa a composição dos danos civis no procedimento sumariíssimo, que pode ser classificada como homologatória e tem efeitos declarados em lei de renúncia ao direito de queixa ou representação, implicando na extinção da punibilidade. Em todos esses casos, há efetiva afetação do mérito, fazem coisa julgada material e impedem uma propositura de ação penal pelo mesmo fato.

31 Sobre isso, ver: COUTINHO, Jacinto Nelson de Miranda. A lide e o conteúdo do processo penal. Curitiba: Juruá, 1989. 
Nesse sentido o ato de arquivamento ${ }^{32}$ tem a natureza jurídica de sentença de arquivamento do inquérito policial ou das peças de informação, sendo absolutamente desnecessário tentar classificá-la entre algumas das categorias já existentes no âmbito da teoria geral do processo (civil). Trata-se, tão somente, de uma sentença de arquivamento do inquérito policial ou das peças de informação, cuja exigência constitucional é precisamente a motivação do ato, na forma do artigo 93, inciso IX, da Constituição $0^{33}$.

\section{HiPóteses de ARQUIVAMENTO dO INQUÉRITO POLICIAL}

Não há qualquer dispositivo no Código de Processo Penal que preveja em que hipóteses o arquivamento do inquérito deve ser requerido pelo órgão legitimado ativo para propor a ação penal ou deferido pelo juízo competente.

Tradicionalmente, a doutrina processual penal apontava que “(...) o arquivamento deve ser requerido - quando presente uma das hipóteses do art. 43 do Código de Processo Penal (...)"34, vez que são as mesmas hipóteses em que o juiz deve rejeitar a denúncia ou a queixa.

De acordo com a redação original do artigo 43 do CPP, a denúncia ou a queixa deve ser rejeitada e, consequentemente, o Ministério Público

32 Vale ressaltar uma importante posição defendida por BETINI, Alexandre. $O$ trancamento do inquérito policial. Dissertação (Mestrado em Direito) - Faculdade de Direito da Universidade de São Paulo, São Paulo, 2012, p. 136, para quem há uma importante diferença entre o arquivamento do inquérito e o trancamento do inquérito. O arquivamento é pedido pelo membro do Ministério Público, não tem natureza de sentença e faz coisa julgada meramente formal, o trancamento é pedido pelo indiciado ou investigado, tem natureza de sentença e faz coisa julgada material. Neste trabalho sustentarse-á conclusão diversa, mas vale ressalvar este importante entendimento muito bem fundamentado.

33 Releve-se a inadmissibilidade da motivação ad relationem com as razões que devem obrigatoriamente ser invocadas pelo Ministério Público no seu ato de requerimento de arquivamento, na forma do artigo 28 do CPP, vez que neste caso faltaria, no dizer de Gomes Filho, as exigências de legitimidade e de imparcialidade (GOMES FILHO, Antonio Magalhães. A motivação das decisões penais. $2^{\mathrm{a}}$ edição. São Paulo: Editora Revista dos Tribunais, 2013, p. 166).

34 JARDIM. Op. cit., p. 175. 
deve pedir o arquivamento do inquérito quando (I) o fato (narrado ${ }^{35}$ ) evidentemente não constituir crime, (II) quando já estiver extinta a punibilidade, pela prescrição ou outra causa ou (III) quando for manifesta a ilegitimidade da parte ou faltar condição exigida pela lei para o exercício da ação penal. Todavia, a Lei no ${ }^{0} 11.719 / 2008$ revogou o artigo 43 do CPP.

Diante da reforma, Rangel passou a entender que:

Os casos em que o inquérito deve ser arquivado não são expressamente previstos em lei, mas se depreende dos arts. 41 c/c 395, ambos do CPP, com a redação da Lei 11.719/2008. São eles:

1. o fato narrado evidentemente não constitui crime;

2. já está extinta a punibilidade;

3. faltar pressuposto processual;

4. ausência de uma condição exigida em lei para o regular exercício do direito de agir. ${ }^{36}$

Todavia, não as hipóteses de arquivamento apontadas por Rangel não são exatamente os casos descritos nos incisos do artigo 395 do CPP.

De acordo com o referido dispositivo, que decerto substituiu o revogado artigo 43 do CPP, o juiz deve rejeitar a denúncia ou queixa, quando (I) a denúncia ou queixa for manifestamente inepta; (II) faltar pressuposto processual ou condição para o exercício da ação penal; ou (III) faltar justa causa para o exercício da ação penal.

Não há dúvida de que o Ministério Público deve requerer o arquivamento do inquérito nas hipóteses dos incisos II e III, mas não na do

35 A lei usava a expressão "narrado", de tal sorte que se remetia à redação dada pelo Ministério Público na denúncia ou dada pelo querelante na queixa, mas é possível concluir que o mesmo raciocínio se aplica ao fato "investigado" e não "narrado", quando o Ministério Público esteja requerendo o arquivamento, já que ao requerer o arquivamento ele não necessariamente narra o fato cujo arquivamento se pede (embora devesse fazê-lo, já que o artigo 28 do $\mathrm{CPP}$ exige que o membro do ministério Público invoque as razões do pedido de arquivamento). É o que Jacinto Coutinho chama de tipicidade aparente (COUTINHO, A natureza cautelar da decisão de arquivamento do inquérito policial. Op. cit., p. 55-56).

36 RANGEL, Paulo. Direito Processual Penal. $23^{\text {a }}$ edição. São Paulo: Atlas, 2015, p. 213. 
inciso I. Ora, a exclusão do primeiro inciso do artigo 395 do CPP entre as hipóteses de pedido de arquivamento encontra-se no fato de que a inépcia da denúncia ou da queixa só poderá ser aferida se for oferecida a denúncia ou a queixa, de tal forma que, sabendo que o pedido de arquivamento é a alternativa ao oferecimento da denúncia ou queixa, é impossível que o Ministério Público peça arquivamento por falha na sua própria atuação que aconteceria futuramente.

Assim, de acordo com esse entendimento, as hipóteses em que o Ministério Público deve pedir o arquivamento são: (1) quando faltar pressuposto processual ou condições para o exercício da ação penal e (2) quando faltar justa causa ${ }^{37}$.

No entanto não se pode ignorar que as hipóteses de absolvição sumária devem ser também as de arquivamento.

Ora, o artigo 397 do CPP, com a redação dada pela Lei $n^{\circ}$ $11.719 / 2008$, prevê que após a resposta escrita à acusação apresentada pelo acusado na forma do artigo 396-A do CPP, “o juiz deverá absolver sumariamente o acusado" em quatro hipóteses: (I) a existência manifesta de causa excludente da ilicitude; (II) a existência manifesta de causa excludente de culpabilidade, exceto inimputabilidade; (III) o fato evidentemente não constitui crime; ou (IV) estiver extinta a punibilidade.

Em todos estes casos a lei não está falando em falta ou deficiência na prova, uma vez que a absolvição por in dubio pro reo deve ser deixada para o momento após toda e qualquer produção de prova, na medida em que enquanto ainda houver possibilidade de produzir provas não pode decidir-se com base na dúvida.

Todas as hipóteses do artigo 397 do CPP são de certeza, seja certeza de atipicidade, ou certeza da incidência de uma excludente (de ilicitude ou de culpabilidade, exceto inimputabilidade), ou certeza de incidência de uma causa de extinção da punibilidade.

37 Nova controvérsia se iniciou com a redação do dispositivo, pois que a posição mais aceita pela doutrina, tributária do entendimento de Afrânio Silva Jardim (JARDIM. Idem) era no sentido de que a "justa causa" tinha a natureza de condição da ação, cujo conceito era "suporte probatório mínimo", todavia, o próprio Jardim mudou sua posição a partir da reforma do artigo 395 do CPP. (vide O Novo Código de Processo Civil e as Condições da Ação. Revista Eletrônica de Direito Processual - REDP, vol. 15, janeiro a junho de 2015). 
Se a certeza existir antes de oferecida a ação penal (denúncia ou queixa), não cabe ao legitimado ativo o ato de acusar. Sua postura deve ser o pedido de arquivamento, mas não com base nas previsões do artigo 395 do CPP, e sim com base nas hipóteses de absolvição sumária do artigo 397 do CPP.

E, mais, não é necessário que o Ministério Público ofereça a denúncia e aguarde o acusado apresentar defesa escrita à acusação para que se proceda à absolvição sumária se, desde o momento em que membro do Ministério Público receber os autos do inquérito for possível verificar, com grau de certeza, jamais de dúvida, a incidência de uma das hipóteses do artigo 397 do CPP.

Desta forma, é possível concluir que após a reforma do Código de Processo Penal implementada especialmente pela Lei ${ }^{\circ} 11.719 / 2008$, as hipóteses de arquivamento são: as do artigo 395, incisos II e III do CPP e também as do artigo 397 do CPP.

\section{Desarquivamento e mutabilidade do arquivamento}

O artigo 18 do Código de Processo Penal prevê que "depois de ordenado o arquivamento do inquérito pela autoridade judiciária, por falta de base para a denúncia, a autoridade policial poderá proceder a novas pesquisas, se de outras provas tiver notícia”. Desta forma, o conteúdo do referido dispositivo deixa claro que o ato de arquivamento não impede que se realizem novas diligências.

Em razão disso, o Supremo Tribunal Federal editou em 1969 a Súmula $\mathrm{n}^{0} 524$, segundo a qual "Arquivado o inquérito policial, por despacho do juiz, a requerimento do promotor de justiça, não pode a ação penal ser iniciada, sem novas provas".

Jardim adverte que o verbete sumular e o artigo 18 do CPP tratam de assuntos diversos. Enquanto o dispositivo legal regula o desarquivamento do inquérito, a Súmula $\mathrm{n}^{\circ} 524$ trata de uma condição específica da ação penal. Isso porque o artigo 18 do CPP fala em "novas pesquisas" em decorrência de "outras provas" de que "tiver notícia", ao passo que a consolidação do entendimento da jurisprudência pela Súmula do Supremo Tribunal Federal prevê que a existência de "novas provas" é a condição para que o promotor de justiça ofereça a "ação penal". 
Todavia, em ambos os casos estamos diante do entendimento de que os efeitos do arquivamento são mutáveis, ou seja, gozam de estabilidade, mas não são definitivos.

Essa mutabilidade dos efeitos da decisão de arquivamento do inquérito policial não dependia, antes da reforma implementada pela Lei $\mathrm{n}^{0} 11.719 / 2008$, da causa que desse ensejo ao arquivamento (todas previstas no artigo 43 do CPP, conforme sua antiga redação, como visto no item anterior), de acordo com a doutrina majoritária.

Para Jardim, a decisão de arquivamento, mesmo na hipótese de ocorrência de extinção da punibilidade (prevista na antiga redação do inciso II do artigo 43do CPP) não teria natureza de sentença, para ele a extinção da punibilidade é o que deve motivar o arquivamento, mas o ato em si é de arquivamento do inquérito porque é "juridicamente impossível julgar onde não há processo ou jurisdição, prolatar sentença em procedimento administrativo investigatório"38. Parece clara a vinculação de Jardim ao conceito de sentença derivado da concepção do Código de Processo Civil de 1973.

Naturalmente as outras duas hipóteses não atingem efetivamente o caso penal, vez que a tipicidade analisada de acordo com o inciso I do revogado artigo 43 do CPP era meramente aparente e as condições da ação (inciso III) eram requisitos de natureza processual para que o autor pudesse exigir a prestação jurisdicional.

Como Jardim entendia que a falta de provas mínimas era a "justa causa", por ele considerada como uma das condições da ação penal, o inciso III supra descrito abrangia esta condição fática ${ }^{39}$.

Todavia, havia vozes dissonantes deste entendimento. Hamilton ${ }^{40}$ afirmava que além das hipóteses previstas no artigo 43 do CPP, havia outras duas possibilidades de arquivamento do inquérito: quando inexistirem indícios de autoria e quando faltar suporte fático mínimo indispensável para uma imputação.

Hamilton, de forma diversa do entendimento trilhado por Jardim, entendia que havia dois casos de arquivamento em que a

\footnotetext{
38 Idem.

39 Idem.

40 Sobre isso: HAMILTON, Sérgio Demoro. O arquivamento definitivo. Revista da EMERJ, Rio de Janeiro, v. 10, n. 39, p. 85-103, 2007.
} 
decisão seria definitiva: na hipótese de atipicidade e de extinção da punibilidade.

Deve se observar que a conclusão apresentada por Hamilton estava coerente com o entendimento do próprio Supremo Tribunal Federal ao interpretar a aplicação do artigo 18 do CPP e sua própria Súmula (de $\left.\mathrm{n}^{\circ} 524\right)$. In verbis:

"Não se revela cabível a reabertura das investigações penais, quando o arquivamento do respectivo inquérito policial tenha sido determinado por magistrado competente, a pedido do Ministério Público, em virtude da atipicidade penal do fato sob apuração, hipótese em que a decisão judicial - porque definitiva - revestirse-á de eficácia preclusiva e obstativa de ulterior instauração da 'persecutio criminis', mesmo que a peça acusatória busque apoiar-se em novos elementos probatórios. Inaplicabilidade, em tal situação, do art. 18 do CPP e da Súmula 524/STF. Doutrina. Precedentes." (STJ - HC 84156, Relator Ministro Celso de Mello, Segunda Turma, julgamento em 26.10.2004, DJ de 11.2.2005)

Isso aponta no sentido de que mesmo antes da reforma do Código de Processo Penal, a ideia de mutabilidade dos efeitos de qualquer decisão de arquivamento do inquérito policial não era pacífica.

Após as mudanças implementadas pela Lei $\mathrm{n}^{0}$ 11.719/2008 e diante da compreensão de que as hipóteses de arquivamento não podem se restringir aos incisos II e III do artigo 395 do CPP, mas incluir os casos de absolvição sumária do artigo 397 do CPP, impõe-se uma nova leitura e interpretação dos efeitos do ato de arquivamento do inquérito policial.

\section{CoIsA JULGADA FORMAL E MATERIAL DO ATO DE ARQUIVAMENTO DO INQUÉRITO POLICIAL: IMUTABILIDADE DOS EFEITOS DO ATO DE ARQUIVAMENTO DO INQUÉRITO POLICIAL E DAS PEÇAS DE INFORMAÇÃO}

Não é incomum que a doutrina processual penal brasileira, firme no comando sumular supra analisado, afirme que "a decisão que decreta o arquivamento do IP não transita em julgado"41.

${ }^{41}$ LOPES JÚNIOR. Op. cit., p. 151. 
Naturalmente esse entendimento só é possível porque no direito processual penal brasileiro perpetuou-se o conceito de sentença que a vincula ao ato de encerramento do processo, bem como à compreensão de que o arquivamento do inquérito policial não é uma sentença.

Nesse sentido seria efetivamente impossível falar-se em trânsito em julgado do ato de arquivamento do inquérito policial, tendo em vista que a clássica concepção de Liebman compreende a coisa julgada como uma qualidade da sentença e não seu efeito ${ }^{42}$.

A autoridade da coisa julgada, que se pode definir, com precisão, como a imutabilidade do comando emergente de uma sentença. Não se identifica ela simplesmente com a definitividade e intangibilidade do ato que pronuncia o comando; é, pelo contrário, uma qualidade, mais intensa e profunda, que reveste o ato também em seu conteúdo e torna assim imutáveis, além do ato em sua existência formal, os efeitos, quaisquer que sejam, do próprio ato. ${ }^{43}$

A preclusão das vias recursais e impugnativas contra a sentença torna a existência do ato judicial formalmente imutável pelo mesmo órgão ou por outro ${ }^{44}$, fazendo coisa julgada formal. Ocorrida a coisa julgada formal, diante da imutabilidade do ato sentencial, os efeitos produzidos pela sentença sobre o caso penal também se tornam imutáveis, ao que se chama de coisa julgada material. A coisa julgada formal é pressuposto da coisa julgada material ${ }^{45}$, sendo que esta opera apenas em relação às sentenças definitivas, ou seja, com apreciação do mérito, que no processo penal se realiza na decisão sobre o caso penal.

Portanto, seria impossível falar-se em imutabilidade dos efeitos do arquivamento do inquérito policial, dado que este não é considerado doutrinariamente, de forma majoritária, uma sentença.

42 LIEBMAN, Enrico Tulio. Eficácia e Autoridade da Sentença: e outros escritos sobre a coisa julgada. Tradução Alfredo Buzaid e Benvindo Aires. Rio de Janeiro: Forense, 1945, p. 15.

43 LIEBMAN. Idem. O artigo 502 do atual CPC se aproxima muito mais do conceito formulado por Liebman do que o artigo 467 do CPC de 1973.

44 TORNAGHI, Helio. Instituições de Processo Penal. Rio de Janeiro: Forense, 1959, p. 456.

45 GRINOVER, GOMES FILHO e FERNANDES. Op. cit., p. 310. 
A concepção proposta neste trabalho, segundo a qual sentença é ato judicial pelo qual se enfrenta ou impede que se enfrente o caso penal, leva a uma nova compreensão a respeito da mutabilidade ou imutabilidade dos efeitos do arquivamento do inquérito policial ou das peças de informação.

Ora, o ato de arquivamento do inquérito policial ou das peças de informação, quando fundado nas hipóteses previstas no artigo 395 incisos II e III do $\mathrm{CPP}^{46}$, impede que se enfrente o caso penal.

E mais, $\mathrm{o}$ ato de arquivamento amparado nas hipóteses previstas no artigo $397^{47}$ incisos I, II e III do CPP enfrenta o caso penal.

Interessante é o caso do ato de arquivamento do inquérito baseado no inciso IV do artigo 397 do CPP, vez que não se trata de um ato que enfrenta o caso penal, mas impede de forma definitiva o seu enfrentamento.

Todos os atos de arquivamento do inquérito policial fazem coisa julgada formal, desde que precluídas as vias recursais ${ }^{48}$, tornando sua existência enquanto ato imutável. Entretanto fazem coisa julgada material apenas os atos de arquivamento do inquérito policial que enfrentem o caso penal ou que impeçam de forma definitiva o enfrentamento do mérito, ou seja, aquelas que se fundam nas hipóteses do artigo 397 do CPP.

$\mathrm{O}$ ato judicial de arquivamento do inquérito fundado nas hipóteses do artigo 395, incisos II e III, do CPP faz coisa julgada apenas formal e, portanto, não enfrenta o caso penal, apenas impede de forma não definitiva que se enfrente. Trata-se de uma sentença cujos efeitos são mutáveis, na forma do artigo 18 do CPP e do verbete sumular $\mathrm{n}^{\circ}$

46 “Art. 395. A denúncia ou queixa será rejeitada quando: I - for manifestamente inepta; II - faltar pressuposto processual ou condição para o exercício da ação penal; ou III - faltar justa causa para o exercício da ação penal.”

47 “Art. 397. Após o cumprimento do disposto no art. 396-A, e parágrafos, deste Código, o juiz deverá absolver sumariamente o acusado quando verificar: I - a existência manifesta de causa excludente da ilicitude do fato; II - a existência manifesta de causa excludente da culpabilidade do agente, salvo inimputabilidade; III - que o fato narrado evidentemente não constitui crime; ou IV - extinta a punibilidade do agente."

48 Vale registrar que não existe uma via impugnativa ou recursal específica na lei processual penal, mas Hamilton defende que nas hipóteses de arquivamento definitivo (HAMILTON. Op. cit.) caberá apelação, havendo legitimidade da vítima para fazê-lo. 
524 do STF. O ato de arquivamento do inquérito policial ou das peças de informação é estável, porém não é imutável ${ }^{49}$.

No sentido de que $o$ ato judicial de arquivamento faz coisa julgada formal, Pacelli afirma que o Código atribui a esta decisão "efeitos idênticos à decisão que impronuncia o réu nos procedimentos do Tribunal do Júri”50.

De outro lado, Badaró, inobstante afirme não se poder "cogitar de coisa julgada", uma vez que "a decisão de arquivamento tem sua estabilidade condicionada ao estado em que foi proferida", reconhece que

Há casos, porém, em que há que se reconhecer que a decisão que determina o arquivamento do inquérito policial torna-se imutável, e impede, definitivamente, tanto o desarquivamento do inquérito policial, quanto a propositura da ação penal. Tem-se, neste caso, coisa julgada material ou, ao menos, um grau de imutabilidade da decisão de arquivamento que impede nova persecução penal pelo mesmo fato. Isso ocorre nas hipóteses em que o arquivamento não decorre de uma mera constatação de insuficiência de elementos de informação sobre a existência material do fato ou de sua autoria. Ao contrário, com base em uma reconstrução fática segura, a partir da investigação realizada, ha um acertamento da inexistência do crime - e não do fato - ou do poder de punir. Assim, nos casos em que se reconhece que os fatos investigados são atípicos, ou estão acobertados por excludente de ilicitude, ou mesmo nas situações de extinção da punibilidade, a decisão de arquivamento será imutável. ${ }^{51}$

Assim, parece claro que Badaró admite a imutabilidade da decisão de arquivamento em certos casos que enumera e mesmo cogita de que ocorra coisa julgada material, mas não o faz de forma definitiva.

49 GRINOVER faz essa distinção entre estabilidade e imutabilidade, aplicando esta à sentença penal absolutória e aquela à sentença penal condenatória, que fica sujeita à possibilidade de Revisão Criminal (GRINOVER, Ada Pellegrini. Coisa julgada penal. In: ANDRADE, Manuel da Costa; ANTUNES, Maria João; SOUSA, Susana Aires de (org.). ESTUDOS em homenagem ao Prof. Doutor Jorge Dias de Figueiredo Dias - volume III. Coimbra: Coimbra Editora, 2009. (Studia Iuridica, 100. Ad Honorem, 5). p. 862).

PACELLI. Op. cit., p. 66.

51 BADARÓ. Op. cit., p. 149/150. 
Em realidade os casos apontados por Badaró como passíveis de fazer "coisa julgada material ou, ao menos, um grau de imutabilidade da decisão de arquivamento" são exatamente aqueles apontados no item anterior deste trabalho como as hipóteses de arquivamento fundados nos casos do artigo 397 do CPP.

$\mathrm{O}$ ato de arquivamento do inquérito policial baseado no artigo 397 do CPP é sentença que enfrenta o caso penal ou impede de forma definitiva que se enfrente o caso penal, de maneira que após sua prolação e preclusas as vias recursais ou impugnativas, opera-se a coisa julgada material, ocorrendo a imutabilidade dos seus efeitos.

Assim, formada a coisa julgada material, pelo que Grinover ${ }^{52}$ chamou de função negativa da coisa julgada, incide a garantia do ne bis in idem, consagrado no artigo 8, número 4, da Convenção Americana de Direitos Humanos (Decreto $\mathrm{n}^{\circ} 678 / 92$ ), segundo o qual o fato objeto do arquivamento (caso penal) não poderá ser discutido em qualquer processo ou procedimento.

\section{Considerações Finais}

Diante de tudo que foi exposto, é possível responder ao problema inicialmente posto, a saber: o arquivamento do inquérito policial é ato judicial cujo conteúdo se torna imutável pela coisa julgada?

Com efeito, o conceito de sentença tributário do Código de Processo Civil de 1973 vincula o ato judicial à sua finalidade, ou seja, o encerramento do processo. Diante da análise das sentenças penais de rejeição da denúncia ou queixa (artigo 395 do CPP), da homologação da transação penal (artigo 76 da Lei $n^{0}$ 9.099/95) e da homologação da composição dos danos civis (artigo 74 da Lei $n^{\circ}$ 9.099/95), constata-se que a existência de um processo não é condição para a existência de uma sentença penal, considerada, neste trabalho, como o ato judicial que enfrenta ou impede que se enfrente o caso penal.

Nesse contexto o arquivamento do inquérito policial ou das peças de informação configura sentença.

52 GRINOVER. Op. cit., p. 861. 
As hipóteses em que o inquérito ou as peças de informação devem ser arquivados depois da reforma promovida pela Lei $\mathrm{n}^{0} 11.719 / 2008$ são os incisos II e III do artigo 395 e o artigo 397 do CPP.

No primeiro caso, arquivamento fundado nos incisos II e III do artigo 395 do CPP ter-se-á uma sentença que impede o enfrentamento do caso penal, porém, precluídas as vias recursais e impugnativas, ocorre tão somente a coisa julgada formal, sendo possível novas pesquisas por parte da autoridade policial quando houver notícia de novas provas, o chamado desarquivamento na forma do artigo 18 do CPP, ou o oferecimento de denúncia ou queixa com base em novas provas, conforme interpretação jurisprudencial sedimentada pelo verbete sumular 524 do STF. Neste caso ocorre a estabilidade da decisão, mas não a imutabilidade dos seus efeitos.

$\mathrm{Na}$ hipótese de arquivamento do inquérito ou das peças de informação baseada nos casos do artigo 397 do CPP, com a preclusão das vias recursais ou impugnativas, opera-se a coisa julgada formal e, como ocorre enfrentamento do caso penal (incisos I, II e III) ou o impedimento definitivo do enfrentamento do caso penal (inciso IV), também a coisa julgada material. Assim, os efeitos da sentença de arquivamento tornam-se imutáveis, de tal forma que pela incidência da garantia do ne bis in idem, previsto no artigo 8 , número 4 , da Convenção Americana de Direitos Humanos (Decreto no 678/92), de tal forma que o caso penal não poderá ser discutido em qualquer processo ou procedimento.

Desta forma, a hipótese inicial de que o arquivamento do inquérito policial é ato judicial cujo conteúdo decisório se torna imutável caso haja enfrentamento do mérito da causa, mais precisamente o caso penal, resta confirmado.

\section{REFERÊNCIAS}

BADARÓ, Gustavo. Processo Penal. $4^{\mathrm{a}}$ edição. São Paulo: Editora Revista dos Tribunais, 2016.

BETINI, Alexandre. O trancamento do inquérito policial. Dissertação (Mestrado em Direito) - Faculdade de Direito da Universidade de São Paulo, São Paulo, 2012. 
COUTINHO, Jacinto. A natureza cautelar da decisão de arquivamento do inquérito policial. Revista de Processo, São Paulo, a. 18, n. 70, abr/jun, 1993.

COUTINHO, Jacinto. A lide e o conteúdo do processo penal. Curitiba: Juruá, 1989. GOMES FILHO, Antonio Magalhães. A motivação das decisões penais. $2^{\mathrm{a}}$ edição. São Paulo: Editora Revista dos Tribunais, 2013.

GRECO FILHO, Vicente. Manual de Processo Penal. 10a edição. São Paulo: Saraiva, 2013.

GRINOVER, Ada Pellegrini, GOMES FILHO, Antonio Magalhães e FERNANDES, Antonio Sacance. Teoria Geral do Processo. 12a edição. São Paulo: Malheiros, 1996.

GRINOVER, Ada Pellegrini. Coisa julgada penal. In: ANDRADE, Manuel da Costa; ANTUNES, Maria João; SOUSA, Susana Aires de (org.). ESTUDOS em homenagem ao Prof. Doutor Jorge Dias de Figueiredo Dias - volume III. Coimbra: Coimbra Editora, 2009. (Studia Iuridica, 100. Ad Honorem, 5). Disponível em: <http://201.23.85.222/biblioteca/index.asp?codigo_sophia=78920>. Acesso em: 17 jul. 2018.

HAMILTON, Sérgio Demoro. O arquivamento definitivo. Revista da EMERJ, Rio de Janeiro, v. 10, n. 39, p. 85-103., 2007. Disponível em: <http://201.23.85.222/ biblioteca/index.asp?codigo_sophia=66942>. Acesso em: 16 jul. 2018.

JARDIM, Afrânio Silva. Direito Processual Penal. 6a edição. Rio de Janeiro: Forense, 1997.

JARDIM, Afrânio Silva. O Novo Código de Processo Civil e as Condições da Ação In: Revista Eletrônica de Direito Processual - REDP, vol. 15, janeiro a junho de 2015. LIEBMAN, Enrico Tulio. Eficácia e Autoridade da Sentença: e outros escritos sobre a coisa julgada. Tradução Alfredo Buzaid e Benvindo Aires. Rio de Janeiro: Forense, 1945.

LOPES JÚNIOR, Aury. Direito Processual Penal. 15ª edição. São Paulo: Saraiva, 2018. MARQUES, Frederico. Elementos de Direito Processual Penal. vol. 2. $2^{\text {a }}$ edição. Rio de Janeiro: Forense, 1965.

PACELLI, Eugênio. Curso de Processo Penal. 16a edição. São Paulo: Atlas, 2012.

PITOMBO, Sérgio Marcos de Moraes. Arquivamento do inquérito policial: sua força e efeito. Revista do Advogado. São Paulo, a III, n. 11, out./dez. 1982.

RANGEL, Paulo. Direito Processual Penal. 23 a edição. São Paulo: Atlas, 2015.

TORNAGHI, Helio. Instituições de Processo Penal. Rio de Janeiro: Forense, 1959.

TOURINHO FILHO, Fernando da Costa. Processo Penal. vol. 4. $24^{\text {a }}$ edição. São Paulo: Saraiva, 2002. 


\section{Informações adicionais e declarações dos autores (integridade científica)}

Declaração de conflito de interesses (conflict of interest declaration): o autor confirma que não há conflitos de interesse na realização das pesquisas expostas e na redação deste artigo.

Declaração de autoria e especificação das contribuições (declaration of authorship): todas e somente as pessoas que atendem os requisitos de autoria deste artigo estão listadas como autores; todos os coautores se responsabilizam integralmente por este trabalho em sua totalidade.

Declaração de ineditismo e originalidade (declaration of originality): o autor assegura que o texto aqui publicado não foi divulgado anteriormente em outro meio e que futura republicação somente se realizará com a indicação expressa da referência desta publicação original; também atesta que não há plágio de terceiros ou autoplágio.

\section{Dados do processo editorial}

(http://www.ibraspp.com.br/revista/index.php/RBDPP/about/editorialPolicies)

- Recebido em: 17/07/2018

- Controle preliminar e verificação de plágio: 21/07/2018

- Avaliação 1: 05/08/2018

- Avaliação 2: 19/08/2018

- Avaliação 3: 20/08/2018

- Decisão editorial preliminar: 22/08/2018

- Retorno rodada de correções: 09/09/2018

- Decisão editorial final: $12 / 09 / 2018$
Equipe editorial envolvida

- Editor-chefe: 1 (VGV)

- Editores-associados: 2 (FC e BC)

- Revisores: 3 


\section{COMO CITAR ESTE ARTIGO:}

SANTORO, Antonio E. R. Arquivamento do inquérito policial: uma análise sobre a imutabilidade dos seus efeitos. Revista Brasileira de Direito Processual Penal, Porto Alegre, vol. 4, n. 3, p. 1095-1118, set./dez. 2018. https://doi.org/10.22197/rbdpp.v4i3.174

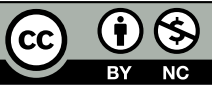

Esta obra está licenciada com uma Licença Creative Commons Atribuição-NãoComercial 4.0 Internacional. 